\title{
РАСШИРЕНИЕ СОТРУДНИЧЕСТВА РОССИИ И ИРАНА *
}

\author{
(C) 2020 Рудакова О.С. \\ доктор экономических наук, профессор Департамента банковского дела и финансовых рынков \\ Финансовый университет при Правительстве Российской Федерации, Россия, Москва \\ E-mail: OSRudakova@fa.ru \\ (C) 2020 Бурцева К.ю. \\ кандидат экономических наук, доцент Департамента бизнес-аналитики \\ Финансовый университет при Правительстве Российской Федерации, Россия, Москва \\ E-mail: aksentiya@mail.ru \\ (C) 2020 Мартыненко Н. Н. \\ кандидат экономических наук, доцент Департамента банковского дела и финансовых рынков \\ Финансовый университет при Правительстве Российской Федерации, Россия, Москва \\ E-mail: NNMartyinenko@fa.ru
}

В последние годы заметен рост взаимного товарооборота России и Ирана, на сегодня он составляет порядка двух миллионов долларов. В статье проведен анализ особенностей сотрудничества России и Ирана, а также возможностей развития интеграционных процессов между Ираном и ЕАЭС. Разработаны научно-обоснованные предложения по развитию взаимовыгодного торговоэкономического сотрудничества России и Исламской Республикой Иран (ИРИ).

Ключевые слова: Россия, Иран, ЕАЭС, сотрудничество, торгово-промышленное сотрудничество, интеграция, возможности.

Отношения между Россией и Ираном имеют длительную историю, однако на современном этапе развитие торгово-экономического сотрудничества приобрело особую актуальность. Вступление в силу Временного соглашения, ведущего к образованию зоны свободной торговли между ЕАЭС и Ираном, дало дополнительный стимул к развитию торгово-экономических отношений России и Ирана на основе партнерства, ведущего к изменениям инвестиционной политики для наших стран.

Анализ возможностей сотрудничества Ирана, России и ее союзников предложено провести на основе применения концепции заинтересованных сторон (стейкхолдеров) в развитии интеграционных процессов между ее участниками. Основные заинтересованные стороны были классифицированы на внешних и внутренних $[1,2]$. Среди внутренних выделены непосредственные участники соглашения, имеющие прямую заинтересованность в интеграции: Иран, Россия и союзники по ЕАЭС. Для них выделены возможности развития процессов сотрудничества в рамках экономического союза. Внешние стейкхолдеры были определены исходя из рисков, возникающих для них в результате активизации интеграционных процессов ЕАЭС, и их возможностей препятствовать данным процессам [1]. Возможности каждой из групп стейкхолдеров представлены на рисунке 1 .

Анализ возможностей и глобализационных процессов в рамках интеграционных объединений позволил определить три сценария дальнейшего развития евразийской интеграции:

1) продленный статус-кво:

- преимущественно независимое развитие стран -членов ЕАЭС;

- фактический отказ от дальнейшей интеграции и ее преимуществ;

2) транзитно-сырьевой мост:

- использование транзитного потенциала ЕАЭС и имеющейся сырьевой базы для расширения интеграционных процессов России и Ирана;

- сосредоточение на интеграции в энергетике и транспорте России и Ирана;

3) собственный центр силы:

- Формирование на Евразийском пространстве центра притяжения инноваций, инвести-

\footnotetext{
* Статья подготовлена по результатам исследований, выполненных за счет средств по государственному заданию Финуниверситета
} 


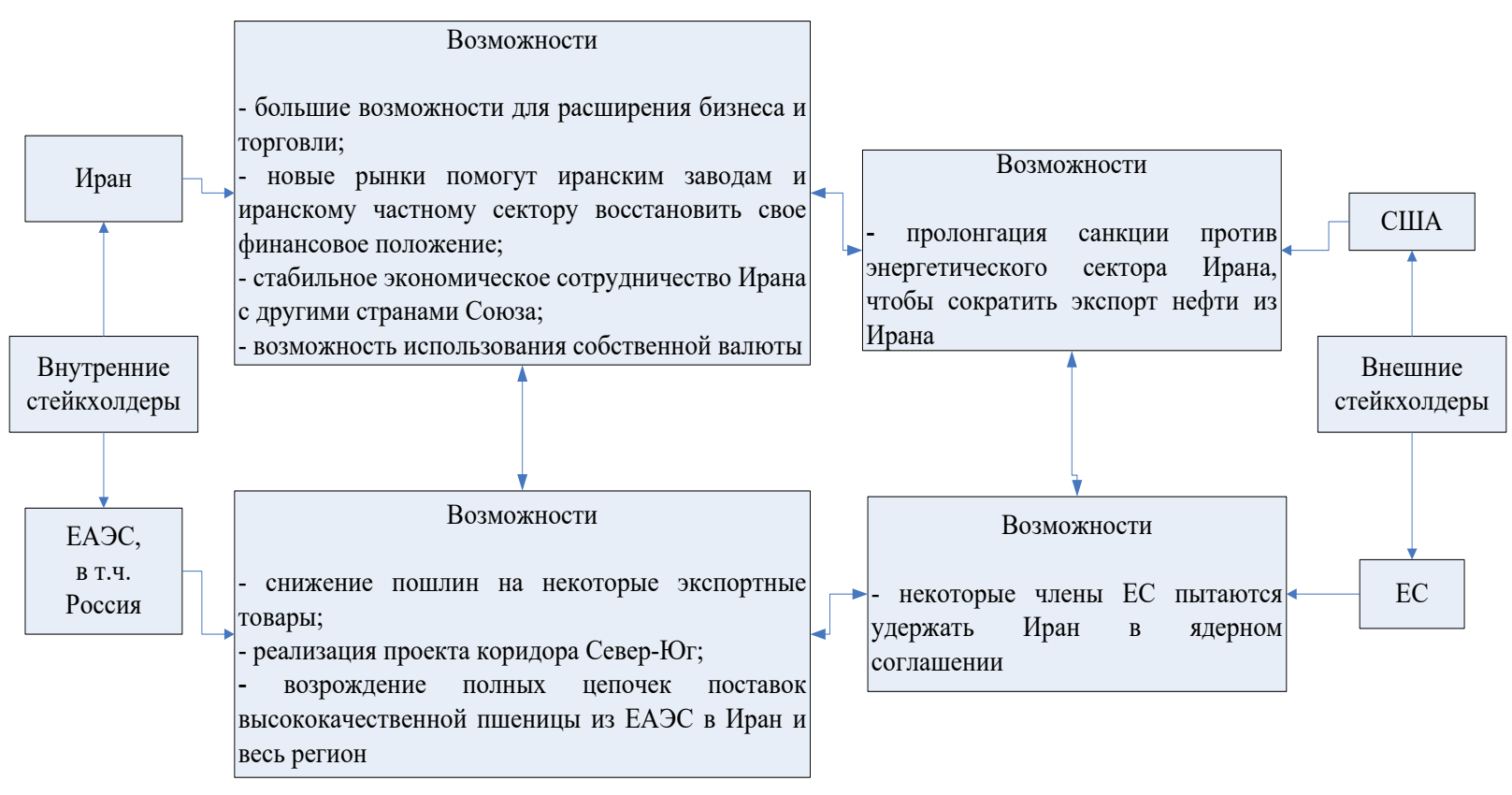

Рисунок 1. Возможности стейкхолдеров

ций, производства конкурентоспособной продукции, высококвалифицированных кадров;

Второй и третий сценарий предполагают развитие следующих основных направлений торгово-промышленного сотрудничества России и Ирана:

- стимулирование опережающего роста промышленного производств, посредством снижения таможенных тарифов и расширения маршрутов автомагистрали «Север-Юг», расширения торговли посредством создания новых и упрочения позиций действующих зон свободной торговли, а также увеличения числа совместных глобальных проектов в ведущих отраслях промышленности;

- развитие конкурентоспособности продукции стран Ирана и России; развитие совместных кооперационных проектов; повышение рентабельности сельскохозяйственных товаропроизводителей; взаимная торговля и развитие механизмов экспорта продукции, инвестиционные проекты; стимулирование экологической и ресурсной эффективности предприятий, развитие кадрового потенциала, обмен кадрами;

- формирование условий для устойчивого и сбалансированного развития промышленности Ирана и России (биотехнологии, нанотехнологии, генная инженерия, развитие и расширение совместных нефтехимических и газохимических предприятий, а также социального или гумани- тарного взаимодействия) на основе развития общих рынков газа, нефти и нефтепродуктов, электро-энергетического, рынка медицинских услуг в соответствии с принятыми программами;

- определение контрольных точек интеграционных процессов заключающихся в развитии сотрудничества в социально-гуманитарной сфере и образовании, формирование территорий инноваций и научно-технического сотрудничества, расширение промышленной кооперации, реализации энергоэффективности и «зеленого роста», развитие транспорта и инфраструктуры, развитии торговой политики, развитии логистической инфраструктуры по переработке, транспортировке и хранению сельскохозяйственной продукции, экологизации сельского хозяйства, формирование прозрачной информационной среды;

- поэтапное расширение экономического сотрудничества в рамках интеграционных объединений (формирование внутреннего единого рынка как надежной платформы обеспечения необходимыми товарами и услугами, а также продвижение конкурентоспособных товаров на внешнем рынке);

- планирование снижения среднего уровня ставок ввозных пошлин Ирана и России (для сельскохозяйственной продукции с 32,2\% до 13,2\% для промышленной продукции с 22,4\% до 15,4\%). 
С учетом всего вышеизложенного ключевыми направлениями концепции подготовки и согласования интеграционных торговоэкономических сотрудничеств Ирана и России предложены:

a) системное представление торговоэкономического сотрудничества стран-участниц ЕАЭС с другими странами и путей перехода от текущих взаимоотношений с ними к желаемым - многосторонним партнерским отношениям базируется на объективном потенциале этой международной организации как надежной базы интеграции в масштабах всего ЕвроАзиатского континента и в частности Ирана и России;

б) в рамках многосторонних интеграционных соглашений мероприятия по защите внутреннего рынка и национальной экономики должны применяться государствамиучастниками в одинаковой мере ко всем из них;

в) для многосторонней интеграции необходимо отталкиваться от принципа наибольшего благоприятствования, когда нормы и принципы, безусловно, должны учитываться при развитии многосторонних международных экономических отношений;

г) использование стейкхолдерского подхода, т.к.:

- совокупность стейкхолдеров способна поддерживать экономику стран-участниц взаимодействия или, напротив, может затруднить и даже заблокировать возможности этого объеди- нения действовать;

- стейкхолдерский подход позволяет создать постоянно действующий механизм инициации деловых проектов в рамках уже достигнутых якорных многосторонних межгосударственных соглашений;

- создание стейкхолдерского механизма даст возможность не ждать проявления стимулирующих бизнес и рост экономического сотрудничества функций таких соглашений, а сознательно управлять их развитием;

- учет потребностей ключевых заинтересованных сторон подобных соглашений позволит достигать синергетического эффекта, сбалансированно выполняя их требования и предупреждая возникновение потенциально конфликтных ситуаций.

Торговые отношения с Ираном достаточно выгодны как для России, так и других стран, входящих в ЕАЭС. Экспорт продукции и товаров России в Иран в два раза превышает иранский экспорт. После заключения временного соглашения с Ираном, российский бизнес, по оценкам экспертов, может увеличить свой доход дополнительно на 150 миллионов американских долларов в год. Заинтересованы в расширении торгово-экономического сотрудничества с Ираном помимо России и другие страны Евразийского союза. Таким образом, актуальность проведенного исследования бесспорна и значима для современного развития взаимоотношений России, Ирана и Стран ЕАЭС.

\section{Библиографический список}

1. Бурцева К.Ю. Анализ преимуществ интеграции для Ирана и ЕАЭС/ Экономические науки - М: 2020.№ 7(188).- С. 109-113.

2. Бурцева К.Ю., Зверинская А.А. Экономическая интеграция ЕАЭС со странами, не входящими в экономический союз / Вестник Самарского государственного университета путей сообщения.- Самара: Самарский гос. Ун-т путей сообщения, 2020.- Вып. 2 (48). - С.22-28.

3. Временное соглашение о ЗСТ ЕАЭС - Иран: вызовы и перспективы для евразийского бизнеса. URL: http:// eurasian-studies.org/archives/8772 Дата обращения: 20.04.2020 г.

4. Аскар Мамин: «Казахстан готов стать логистическим мостом между Ираном и ЕAЭС»... URL: https://kursiv. kz/news/politika/2018-05/askar-mamin-kazakhstan-gotov-stat-logisticheskim-mostom-mezhdu-iranom-i-eaes Дата обращения: 20.04.2020 г.

5. Первые успехи торгового соглашения Ирана с EAЭC URL: https://www.iran.ru/news/economics/114974/ Pervye_uspehi_torgovogo_soglasheniya_Irana_s_EAES Дата обращения: 20.04.2020 г.

6. Временное соглашение, ведущее к образованию зоны свободной торговли между ЕАЭС и Ираном URL: http://www.eurasiancommission.org/ru/nae/news/Pages/17-05-2018-1.aspx Дата обращения: 30.04 .2020 г.

7. Петров А.М. «КОНТРОЛЬ ЗА ДВИЖЕНИЕМ ДЕБИТОРСКОЙ И КРЕДИТОРСКОЙ ЗАДОЛЖЕННОСТИ» Современный бухучет. 2004. № 9. С. 38. 
8. Карпова Т.П., Петров А.М., ГорбатковаГ.А., СамаринаЛ.Б., ДашкинаГ.Г., Сидорова М.И., Сабанин Р.Л., Ситникова В. А., ЛистопадЕ.Е. «БУХГАЛТЕРСКИЙ УЧЕТ В СФЕРЕ УСЛУГ» учебник для студентов высшего профессионального образования, обучающихся по специальности 080109 «Бухгалтерский учет, анализ и аудит» / Под редакцией М.А. Вахрушиной; Министерство образования и науки Российской Федерации, Федеральное государственное учреждение «Федеральный институт развития образования». Москва, 2011. Сер. Читай

9. Петров А.М., МельниковаЛ.А. «ФОРМИРОВАНИЕ ОТЧЕТНОСТИ В СООТВЕТСТВИИ С ТРЕБОВАНИЯМИ МСФО КАК ОБЪЕКТИВНАЯ НЕОБХОДИМОСТЬ НА СОВРЕМЕННОМ ЭТАПЕ РАЗВИТИЯ ЭКОНОМИКИ РФ» Проблемы современной экономики. 2017. № 2 (62). С. 105-107.

10. Петров А.М., Коняхин А.Н. «УЧЕТНАЯ ПОЛИТИКА ПРИ ПОДГОТОВКЕ ПЕРВОЙ ОТЧЕТНОСТИ СОГЛАСНО МСФО» Международный бухгалтерский учет. 2013. № 11 (257). С. 2-15.

11. Петров А.М., Лымарь М. П. «СОСТАВ БУХГАЛТЕРСКОЙ ОТЧЕТНОСТИ В РОССИИ И КИТАЕ» МежДУНароднЫЙ бухгалтерский учет. 2014. № 31 (325). С. 28-37.

12. Петров А.М., Лымарь М.П. «СРАВНИТЕЛЬНАЯ ХАРАКТЕРИСТИКА ОСНОВНЫХ ПОЛОЖЕНИЙ ЗАКОНОВ, РЕГУЛИРУЮЩИХ БУХГАЛТЕРСКИЙ УЧЕТ В КИТАЕ И РОССИИ» МеждународныЙ бухгалтерскиЙ учет. 2013. № 40 (286). С. 52-60.

13. Петров А.М., Лымарь М. П. «СРАВНИТЕЛЬНЫЙ АНАЛИЗ БУХГАЛТЕРСКОГО УЧЕТА АКТИВОВ В РОССИИ И КИТАЕ» Международный бухгалтерский учет. 2014. № 27 (321). С. 34-48.

14. Петров А.М. «ОБЩЕСТВЕННОЕ ПИТАНИЕ 6 в 1: учетная политика, документооборот, калькулирование себестоимости, бухгалтерский учет, налоги, отчетность» / А. М.Петров. Москва, 2011. Сер. Полное руководство бухгалтера 